\title{
Subcolectomy and symphyseal distraction-osteotomy using a spacer of spirally fashioned orthopedic wire: a treatment option for cats with pelvic canal stenosis, megacolon and obstipation
}

\author{
Subcolectomia e distração da sínfise púbica com espaçador de fio ortopédico espiralado: uma \\ opção de tratamento para gatos com estenose do canal pélvico, megacolon e obstipação
}

\author{
Fabiane Azeredo Atallah ${ }^{\text {I Ricardo Siqueira Silva }{ }^{I I} \text { André Lacerda de Abreu Oliveira }}$ \\ Heloisa Justen Moreira Souza ${ }^{\mathrm{IV}}$
}

\section{ABSTRACT}

The use of two cerclages with wire spirals as distractor spacers was evaluated for the correction of pelvic stenosis in felines. A three-year-old, mixed-breed, male feline was taken to the Veterinary Hospital of the UFRJ. It presented symptoms of constipation, dyschezia, hyporexia and mild apathy. On radiographic examination, a deformation of the pelvic bones and $a$ narrowing of the pelvic canal were detected. The patient underwent pelvic stenosis correction surgery. Two spirals were made with cerclage wire and 2.0-mm diameter Steinmann pins; coupled to the chuck of a drill, the pins were wrapped with cerclage wire, running laps around the pin. Then, the coils were positioned in the space formed by separating the hemipelves and stabilized by keeping them separated to the desired opening. Effectiveness of the technique was evidenced by measurements made using new radiographic images in comparison with the images obtained before the surgical procedure. There were evident decreases in the sacro-ischium line and pubic line of 3.98 and 3.18, demonstrating an increase of approximately $21 \%$ in the pelvic canal diameter. The animal showed no apparent macroscopic or radiographic reaction. The preliminary clinical application of the adapted pelvic distraction technique is relevant for allowing the appropriate correction of a stenosis of the pelvic girdle and its consequences, representing a major technical and scientific innovation in the correction.

Key words: symphysiotomy, surgery, subcolectomy, feline.

RESUMO

Avaliou-se o uso de duas espirais confeccionadas com fio de cerclagem como preenchimento distrator para correção de estenose pélvica em felinos. Foi atendida no Hospital
Veterinário da UFRJ um felino macho, sem raça definida com idade de 3 anos, apresentando sintomas de constipação, disquezia, hiporexia e apatia leve. Ao exame radiográfico, observou-se deformação de ossos da pelve com estreitamento do canal pélvico. $O$ animal foi operado para correção da estenose pélvica. Foram confeccionados dois espirais com fio de cerclagem e um pino de Steinmann de 2,0mm de diametro acoplado ao mandril de uma perfuratriz, envolveu-se este pino com o fio de cerclagem, executando voltas ao redor do pino. Em seguida, os espirais foram posicionados no espaço formado pela separação das hemipelves, e estabilizados, mantendo-as separadas com a abertura desejada. A efetividade da técnica foi evidenciada por medições feitas através de novas imagens radiográficas, permitindo assim uma comparação com a imagem obtida anteriormente ao procedimento cirúrgico. A aplicação clínica da técnica é relevante por permitir que a correção apropriada da estenose da cintura pélvica e suas consequências representa uma importante inovação técnica e científica na correção dessa condição.

Palavras-chave: sinfisiotomia, cirurgia, subcolectomia, felinos.

\section{INTRODUCTION}

Pelvic fractures represent $20-30 \%$ of all fractures that affect cats. For the most part, they are due to falls and motor vehicle trauma. In a study of 103 cats with pelvic fractures, $90 \%$ had fractures that involved the pelvic floor, $60 \%$ had sacroiliac dislocation, and $48.5 \%$ had fractures in the body of the

\footnotetext{
'Programa de Pós-graduação em Medicina Veterinária, Unidade de Experimentação Animal, Universidade Estadual do Norte Fluminense (UENF), Avenida Alberto Lamego, 2000, 28013-602, Campos dos Goytacazes, RJ, Brasil. E-mail: fabiane-vet@hotmail.com. Corresponding author.

"Universidade Federal do Rio de Janeiro (UFRJ), Rio de Janeiro, RJ, Brasil.

IIIUniversidade Estadual do Norte Fluminense (UENF), Campos dos Goytacazes, RJ, Brasil.

${ }^{\text {IV } U n i v e r s i d a d e ~ F e d e r a l ~ R u r a l ~ d o ~ R i o ~ d e ~ J a n e i r o ~(U F R R J), ~ R i o ~ d e ~ J a n e i r o, ~ R J, ~ B r a s i l . ~}$
} 
ileum (MEESON \& COO, 2011). It is usual to find out combinations of these fractures with the presence of multiple fragments. Conservative treatment increases the probability of poor bone union and pelvic canal stenosis (BURTON, 2011). This pelvic anatomical deformity leads to complications, such as dystocia, constipation and obstipation, which can lead to the formation of megacolon (MEESON \& COO, 2011). The prolonged retention of feces in the colon leads to increased water absorption from the fecal mass, which promotes a greater hardening or stool impaction, generating other associated symptoms, as dyschezia, megacolon and tenesmus. In cats, a perianal hernia may develop due to the dyschezia ,megacolon and weakening of the pelvic muscles (BURTON, 2011).

Surgical widening of the pelvis is the recommended treatment for cats with stenosis and recurrent clinical signs of constipation (COLOPYPOULSEN et al., 2005). Pubic symphysis is exposed through a ventral midline approach, and the fibrocartilage that joins the two pubic bones is separated in a symphysiotomy. After osteotomy of the symphysis, the maintenance of a gentle lateral distraction of each side of the hemipelvis allows greater widening of the pelvic canal by the application of various types of implants, including metal or plastic spacers (LEITGHTON, 1969; NIKITAS et al., 2009), autogenous or halogen containing bone grafts, or implants composed of methyl methacrylate (McKEE \& WONG, 1994).

The purpose of this report is to describe the successful treatment of a feline with stenosis of the pelvic canal, megacolon, severe constipation and perineal hernia, emphasizing the combination of the use of the pelvic distraction technique with placement of two metal wires in spiral shapes, perineal hernia repair and subcolectomy.

\section{MATERIALS AND METHODS}

A 3-year-old male domestic mixed-breed cat had been taken to the hospital showing symptoms of constipation, dyschezia, hyporexia and mild apathy seven days previous. During the physical examination, a volume increase in the left perianal region, compatible with perianal hernia resulting from repeated defecation effort was checked, and with abdominal palpation, a distended colon was noticed with the presence of an irregular fecal mass, tubular and compressible. The information obtained during the case reporting revealed that the animal had suffered a blow six months prior to the examination (Tables 1 and 2). Radiographic examination revealed an ileum body fracture with bony callus formation on the right side, which caused the narrowing of the pelvic canal, beyond the left ischium body fracture. Radiographs in the lateral and ventrodorsal positions of the pelvic and abdominal region also assisted in the observation of megacolon. Widths observed between the coxal tuberosities, transversal diameter, acetabula and ischial tuberosities, were $4.6 \mathrm{~cm}, 2.7 \mathrm{~cm}, 2.3 \mathrm{~cm}$ and $4.9 \mathrm{~cm}$, respectively (Figures 1 and 2 ).

The animal was anaesthetized with $5 \mathrm{mg}$ $\mathrm{kg}^{-1}$ ketamine and $0.5 \mathrm{mg} \mathrm{kg}^{-1}$ diazepam, allowing the execution of a digital anorectal exam, with the aid of the index finger, to confirm the narrowing of the canal and the rupture of the pelvic musculature. An enema was performed with a combination of fragmentation and manual removal of the retained stool. Clinical treatment consisted of the provision of canned food, $0.5 \mathrm{ml} \mathrm{kg}^{-1}$ lactulose every 12 hours and, in the absence of defecation over a 24 hour period, a glycerin suppository. Surgical repair of the perineal hernia was performed due to the marked dyschezia and animal discomfort. Despite this, 10 days after surgery and with clinical treatment, the animal again presented constipation. It was then decided to perform additional surgery to increase the diameter of the pelvis by osteotomy of the pelvic symphysis just after insertion of a urethral catheter. Pubic symphysis was exposed through a ventral midline approach, with the elevation and retraction of the adductor and gracilis muscles allowing the visualization of the symphysis. Separation of the hemipelves was achieved through the use of an orthopedic number 4 chisel and hammer. Prior to separation, with the aid of a $1.5 \mathrm{~mm}$ Steinmann pin, four holes were drilled, two on each edge of the hemipelves aligned on each side, obliquely to allow the

Table 1 - Standard width values between the hip bones of cats (female and male).

\begin{tabular}{|c|c|c|c|c|}
\hline Feline over 2 years of age & $\begin{array}{l}\text { q (width between the } \\
\text { coxal tuberosities) }\end{array}$ & $\mathrm{s}$ (transversal diameter) & $\begin{array}{l}\mathrm{t} \text { (width between the } \\
\text { acetabula) }\end{array}$ & $\begin{array}{l}\mathrm{u} \text { (width between the } \\
\text { ischial tuberosities) }\end{array}$ \\
\hline Males & $4.82 \mathrm{~cm}$ & $2.72 \mathrm{~cm}$ & $2.65 \mathrm{~cm}$ & $4.77 \mathrm{~cm}$ \\
\hline Females & $4.31 \mathrm{~cm}$ & $2.76 \mathrm{~cm}$ & $2.60 \mathrm{~cm}$ & $4.41 \mathrm{~cm}$ \\
\hline
\end{tabular}


Table 2 - The width values between the cat's hip bones, obtained before and after the cat had undergone osteotomy.

\begin{tabular}{|c|c|c|c|c|}
\hline & Q & $\mathrm{s}$ & $\mathrm{T}$ & $\mathrm{U}$ \\
\hline $\begin{array}{l}\text { Radiography } \\
\text { before surgery }\end{array}$ & $4.6 \mathrm{~cm}$ & $2.7 \mathrm{~cm}$ & $2.3 \mathrm{~cm}$ & $4.9 \mathrm{~cm}$ \\
\hline $\begin{array}{l}\text { Radiography } \\
\text { after surgery }\end{array}$ & $4.6 \mathrm{~cm}$ & $2.7 \mathrm{~cm}$ & $2.5 \mathrm{~cm}$ & $5.1 \mathrm{~cm}$ \\
\hline $\begin{array}{l}\text { Schematic } \\
\text { design }\end{array}$ & $4.82 \mathrm{~cm}$ & $2.72 \mathrm{~cm}$ & $2.65 \mathrm{~cm}$ & $4.77 \mathrm{~cm}$ \\
\hline
\end{tabular}

passage of two $0.8 \mathrm{~mm}$ steel wires for cerclage. Before the steel wires were inserted, two spiral cerclage wires of the same diameter mentioned above were made, as follows: With a $2.0-\mathrm{mm}$ diameter Steinmann pin attached to the chuck of a drill, this pin was wrapped with the cerclage wire a total of six times to make the spiral, according to the desired enlargement of the pelvic symphysis (Figure 3). Then, the coils were positioned in the space formed by separating the hemipelves, and the cerclage wire was passed through the first hemipelvic edge hole. The wire penetrated the spiral placed between the hemipelves and was passed through the edge of the second hemipelvis and twisted with the other end of the cerclage wire to position and stabilize the spiral edges, keeping them separated to the desired opening. The same procedure was performed with the other coil.

The fascia of the gracilis and adductor muscles were sutured to close the pelvic cavity. An approximation of the muscles was facilitated by adducing the hind limbs. The urethral catheter introduced was removed during surgery. Immediately after surgery, feces in the colon and rectum were evacuated as much as possible through the use of external massage.

Subsequently, a radiographic examination was performed to visualize the pelvic canal expansion,

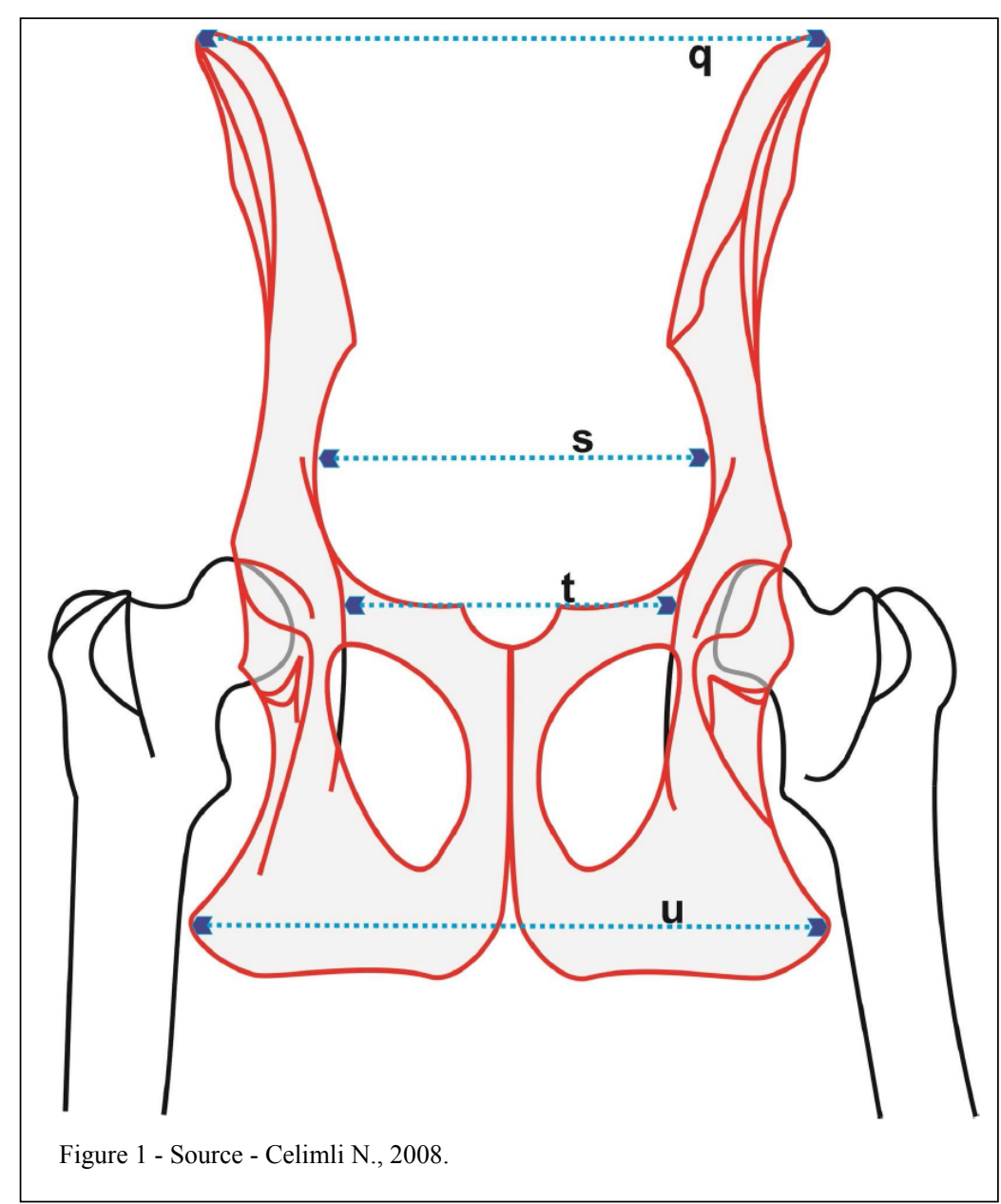

Ciência Rural, v.46, n.8, ago, 2016. 


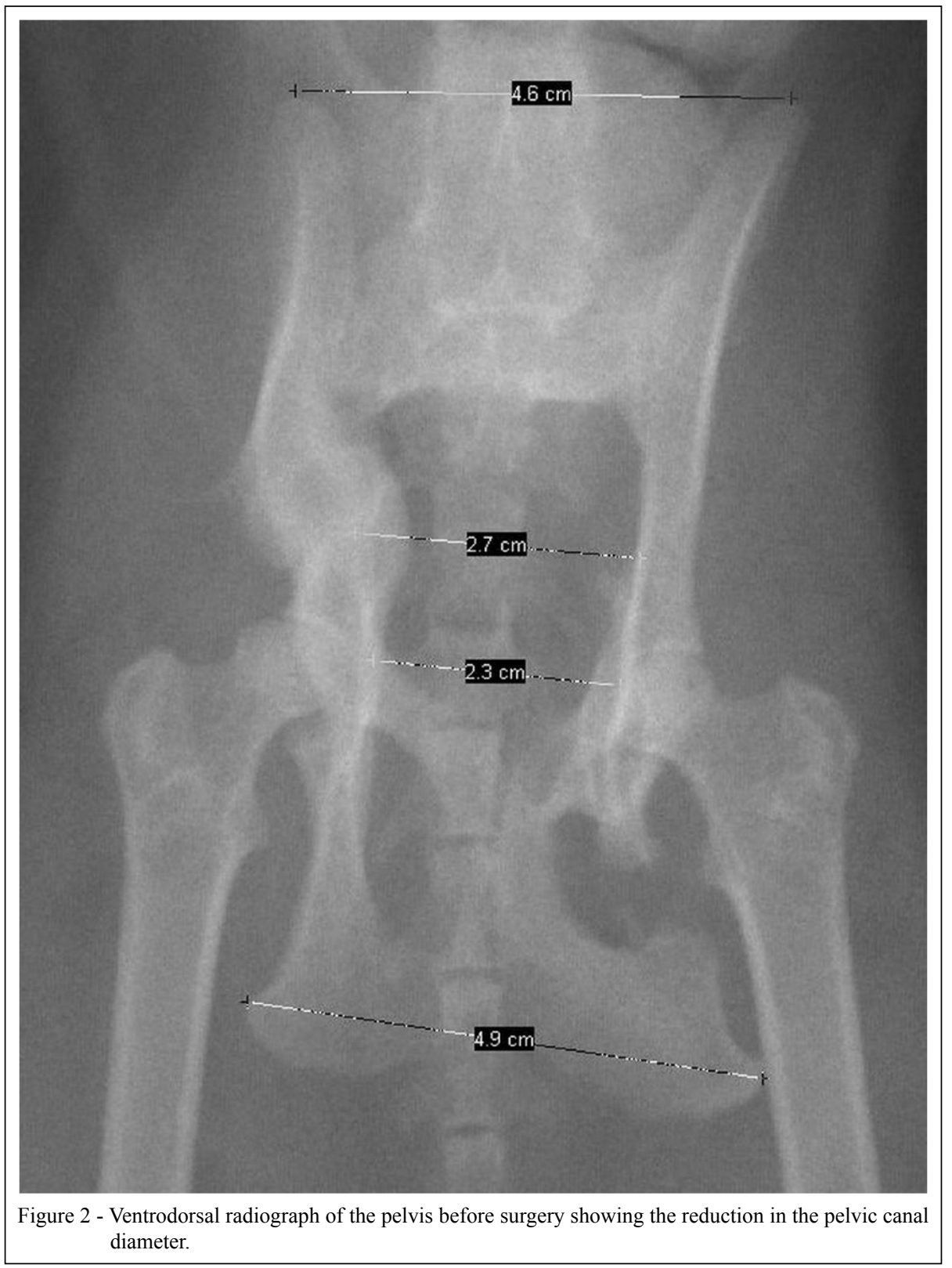

which comprised an increase of $0.2 \mathrm{~cm}$ in the pelvis diameter (Figure 4). A diet including the use of prokinetic laxatives and a dose of $2.0 \mathrm{mg} / \mathrm{kg}$ ranitidine was followed for 20 days. After this period, the cat presented moderate constipation that was refractory to medication and food therapy. Exactly one month after surgery, a subcolectomy was indicated, with the removal of $80 \%$ of the colon due to the presence of megacolon, which was then the only reason that the animal was having difficulty to expel e feces. During the postoperative period, the same protocol mentioned above was performed in addition to a soft diet after fasting for 12 hours postoperatively. Clinical and radiological follow up of the feline was continued for six months.

The animal showed no reaction to the implant. Ten days after surgery, it returned to the clinic for further evaluation and stitch removal. The surgical wound had healed perfectly; there was no swelling in the operated area and no sign of constipation or discomfort during defecation. The owner was instructed to continue with paste food to avoid future recurrences. After a period of one year, the owner reported that the animal showed no clinical

Ciência Rural, v.46, n.8, ago, 2016. 


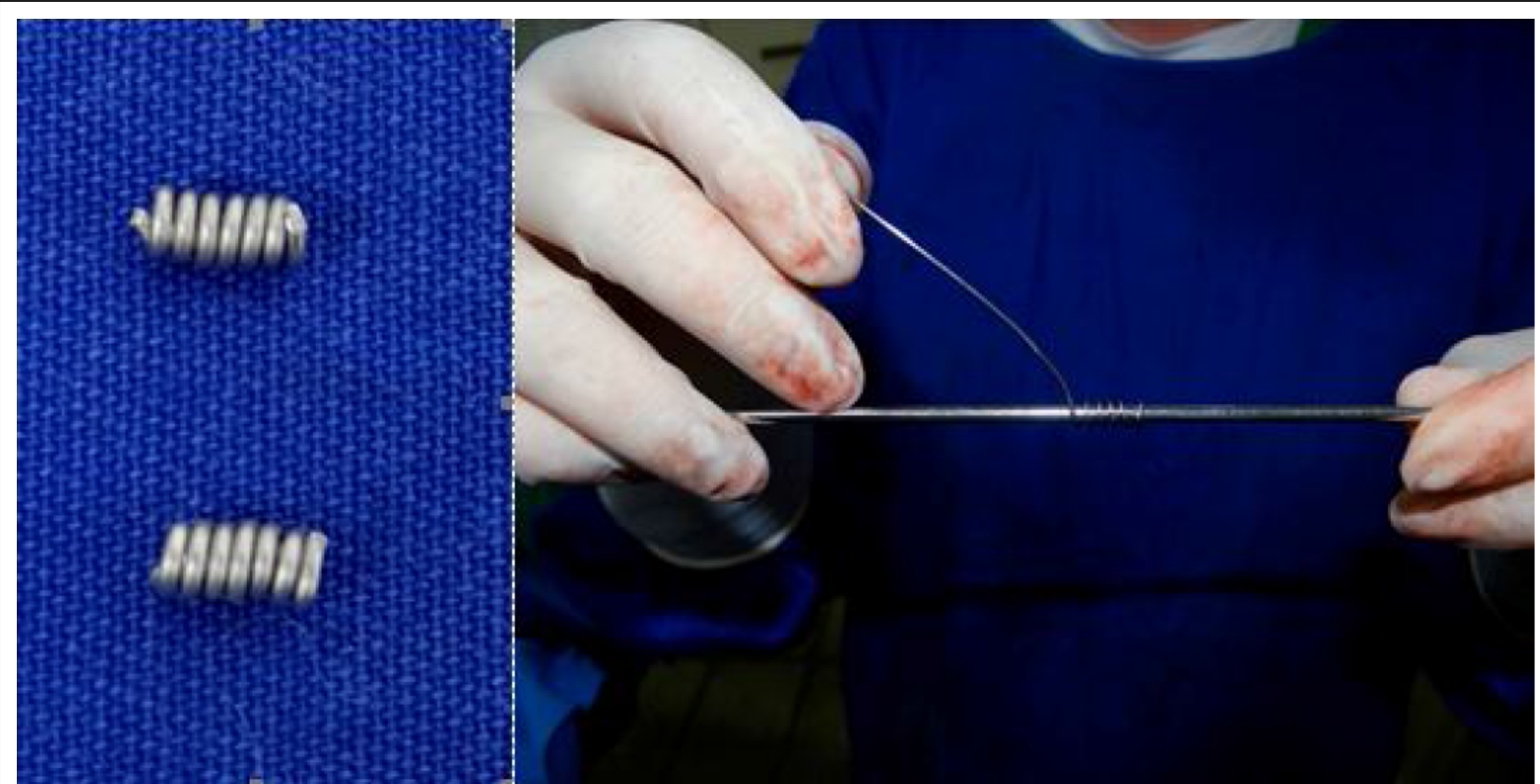

Figure 3 - Development of the metal spiral spacers used in the stabilization of the pelvic symphysis.

change, but because he had other cats, the soft or semi-pasty diet was sporadically not maintained.

\section{DISCUSSION}

Constipation, if not diagnosed early and treated properly, can become gradually worse; then, a striking case emerges, in most cases with obstipation. Obstipation is an untreatable form of constipation and is extremely uncomfortable for the animal. In this case, the impaction of feces is so severe that the obstipated animal usually cannot remove their own feces (MEESON \& COO, 2011). Megacolon is defined as a distension of the intestine diameter, causing severe impairment of intestinal motility. Megacolon due to mechanical changes occurs most often due to compression fractures of the pelvis. Perianal hernias are associated with megacolon in feline species. Tenesmus may lead to the weakening of the muscle pelvic girdle. The perianal hernia surgery was prioritized because of atrophy and weakness of these muscle groups hindering the issuance of the fecal mass. However, even instituting a soft and laxative diet after hernia repair, it was not enough to return to normal defecation (McKEE \& WONG, 1994).

Conservative treatment is an option for fractures of the pelvis and sacroiliac dislocations in pelvic trauma. However, this choice may lead to the development of pelvic fractures and severe compression, which enables the narrowing of the pelvic canal. One of the main causes of dystocia, constipation and obstipation in cats is the narrowing of the pelvic canal (WASHABAU \& HOLT, 1999). Numerous surgical techniques are employed for pelvic surgical distraction to widen the pelvic canal. Pelvic symphysis osteotomy distraction technique is used when the symphysis remains intact with canal stenosis and when the diameter of the pelvic channel has been reduced horizontally instead of vertically (CELIMLI et al., 2008). Use of metal spacers in a spiral after the distraction of the hemipelves was the first choice of our team because this type of material was available in our hospital and making the spacers was easy and affordable.

Use of spacers for the symphysis osteotomy provides a more stable configuration, thus avoiding the medial displacement of the hemipelves postoperatively. The use of autogenous bone may not be preferable to the use of a spacer as an implant, as it likely would not maintain the distraction (McKEE \& WONG, 1994). In addition, its use requires the performance of a second operation in the animal to obtain the graft (MATHIESEN et al., 1991), which involves increased operative time, anesthesia risk, cost, pain and potential complications. Moreover, allografts are not always available, and there is still the risk of rejection.

This explains why bone grafts have not been used to retain the pelvic symphysis distraction

Ciência Rural, v.46, n.8, ago, 2016. 


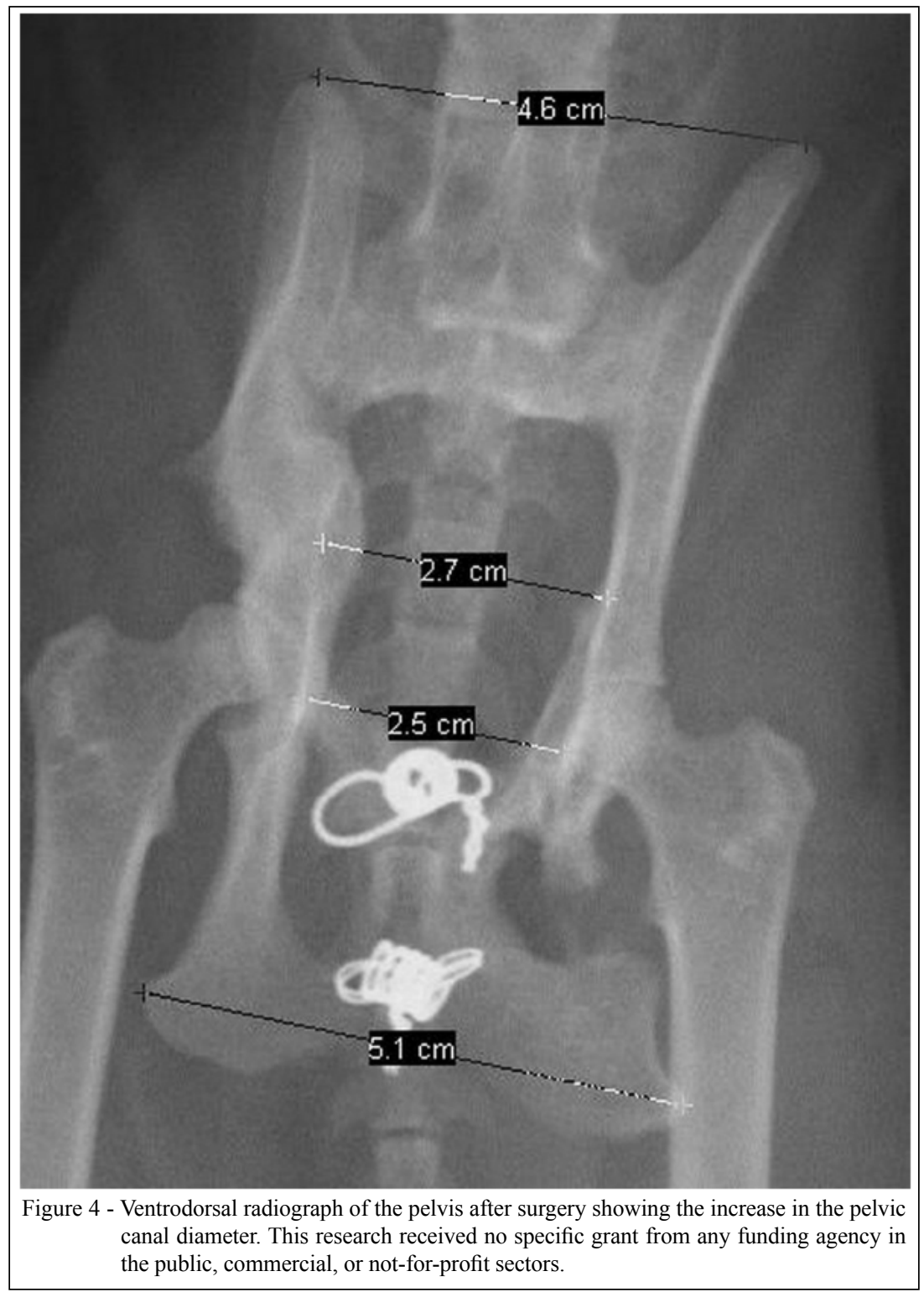

(McKEE \& WONG, 1994; COLOPY-POULSEN et al., 2005). There are reports relating the use of plates, in which authors describe results of frequent instability.

The technique used in this study did not require specialized instruments. In addition, this technique is versatile because it allows the construction of a spacer with appropriate length and width for the desired degree of distraction. Diameter of the wire used to construct the spacer (Steinmann pin $2.0 \mathrm{~mm}$ ) was the most effective in our animal; however, this can be adjusted individually based on the pelvic conformation and body weight of each cat. The authors recommend that the diameter of the wire used to attach the spacers to the pelvis have a diameter
0.6 or $0.8 \mathrm{~mm}$; otherwise, the bone may fracture in the hole when it is tightened due to the drill.

Extension of the channel must be adapted to each individual and determined by rectal palpation during surgery and by the pelvic radiographs and clinical signs (SCHARADER, 1992). Two spacers were placed due to the pelvic conformation; the use of more than one spacer is recommended.

Effectiveness of the technique performed was further evaluated by measurements made using new radiographic images, thus allowing a comparison with the image obtained before the surgical procedure. A decrease between the sacro-ischiatic line and the pubic line from 3.98 to 3.18 can be observed, 
demonstrating an increase of approximately $21 \%$ in the diameter of the pelvic canal.

The symphysiotomy technique as reported SCHRADER (1992) provides resolution for pelvic canal stenosis, thereby enabling the animal to defecate without further complications when it does not present megacolon. If, in cases of pelvic fractures, a fracture alignment is performed, the risk of narrowing is virtually non-existent; in cases where there is channel narrowing and the symphysiotomy is performed within six months after the trauma, the likelihood of perianal hernia formation and megacolon greatly decreases. Thereafter, the risk of complications increases to nearly $100 \%$ of the cases.

The prolonged feces retention caused by the mechanical obstruction of the pelvis for a period of six months likely led to a disturbance in the filaments that activate the smooth muscle and a loss of function. Megacolon was confirmed not to be a response to drug therapy,to the enlargement of the pelvis or to the hernia repair(SCHARADER, 1992). In this case, a subcolectomy was indicated. There was a clear improvement in the cat's quality of life, without the need for supporting enemas or drug therapies, one year after the surgical procedures. Increased pelvic girdle allowed the evacuation of feces without obstacles, decreasing the chance of constipation and megacolon recurrence. The distraction of the pelvis as a form of treatment can be performed alone in cats with chronic constipation, when the muscles of the colon are only hypertrophied and have tone. Generally, this correction should occur within six months of presentation of clinical signs. However, some cats have benefited from the distraction of the pelvis with spiral spacers when the clinical signs of chronic constipation and obstipation were present for more than six months, as reported by PRASSINOS et al. (2007).

\section{CONCLUSION}

Subcolectomy associated with pelvic distraction showed to be effective for this case of megacolon correction and obstipation associated with post-traumatic stenosis of the pelvic girdle. Moreover, this technique has the advantage of being fast and inexpensive, has easy-to-acquire material and facilitates the degree of desired pelvic distraction both in length and in width during surgery.

\section{BIOETHICS AND BIOSSECURITY COMMITTEE APPROVAL}

We authors of the article entitled "Subcolectomy and symphyseal distraction-osteotomy using a spacer of spirally fashioned orthopedic wire: A treatment option for cats with pelvic canal stenosis, megacolon and obstipation" declared, for all due purposes, that the project that gave rise to the present data of has not been submitted for evaluation to the Ethics Committee of the Universidade Estadual do Norte Fluminense, but we are aware of the content of the Brazilian resolutions of the Conselho Nacional de Controle de Experimentação Animal (CONCEA) < http://www.mct. gov.br/index.php/content/view/310553.html $>$ if it involves animals. Thus, the authors assume full responsibility for the presented data and are available for possible questions, should they be required by the competent authorities.

\section{REFERENCES}

BURTON, J.N. Composite fixation of comminuted ilial wing fractures in cats: three cases. Journal Feline Medicine and Surgery, v.13, p.376-382, 2011. Available from: <http://jfm. sagepub.com/content/13/5/376.long $>$. Accessed: Jun. 10, 2015. doi: 10.1016/j.jfms.2011.03.013.

CELIMLI, N. et al. Radiographic pelvimetry and evaluation of radiographic findings of the pelvis in cats with dystocia. Tierärztl Praxis, v.36, p.277-284, 2008. Available from: <https://scholar. google.com.br/scholar?hl=es\&as_sdt=0,5\&as_vis=1\&q=Radiogra phic + pelvimetry + and + evaluation + of + radiographic + findings + of $+t$ he+pelvis + in + cats + with + dystocia $>$. Accessed: Jul. 13, 2015.

COLOPY-POULSEN, S.A. et al. Managing feline obstipation secondary to pelvic fracture. Compendium on Continuing Education for the Practising Veterinarian, v.27, s.9, p.662670, 2005. Available from: <http://www.kestrel.ws/erasmus/docs/ PV_27_09_662.pdf>.Accessed: Jun. 20, 2015.

LEITGHTON, R.L. Symphysectomy in the cat and the use of a steel insert to increase pelvic diameter. Journal of Small Animal Practice, v.10, p.355-359, 1969.

MATHIESEN, D.T. et al. Subtotal colectomy for the treatment of obstipation secondary to pelvic fracture mal union in cats. Veterinary Surgery, v.20, p.113-117, 1991.

McKEE, W.M.; WONG, W.T. Symphyseal distraction-osteotomy using an ulnar autograft for the treatment of pelvic canal stenosis in three cats. Veterinary Record, v.134, p.132-135, 1994. Available from: <http://jfm.sagepub.com/content/9/1/23.long $>$. Accessed: Jul. 03, 2015. doi: 10.1016/j.jfms.2006.06.001.

MEESON, R.; COO, S. Management of pelvic pelvic trauma trauma, neurological damage, urinary tract disruption and pelvic fractures. Journal Feline Medicine and Surgery, v.13, p.347-361, 2011. Available from: <http://www.sciencedirect.com/science/ article/pii/S1098612X11000908>. Accessed: Jun. 20, 2015. doi: 10.1016/j.jfms.2011.03.011.

SCHARADER, S.C. Pelvic osteotomy as a treatment for obstipation in cats with acquired stenosis of the pelvic canal: six cases. Journal of the American Veterinary Medical Associationn, v.200, p.1978-1989, 1992

WASHABAU, R.J.; HOLT, D. Pathogenesis, diagnosis, and therapy of feline idiopathic megacolon. Veterinary Clinics of North America: Small Animal Practice, v.29, p.589-603, 1999. Available from: <http://www.sciencedirect.com/science/article/ pii/S0195561699500363>. Accessed: Jul. 13, 2015. doi:10.1016/ S0195-5616(99)50036-3. 